\title{
FLOW OF THE BRUNT ICE SHELF, ANTARCTICA, DERIVED FROM LANDSAT IMÁGES, 1974-85
}

\author{
By D. A. SIMMONS \\ (British Antarctic Survey, Natural Environment Research Council, High Cross, Madingley Road, Cambridge \\ CB3 0ET, England)
}

ABStract. Satellite images recorded in 1973, 1974, and 1985 of the Brunt Ice Shelf are compared. There are sufficient identifiable features moving with the ice shelf to show flow patterns over an area of $\sim 10000 \mathrm{~km}^{2}$. Velocities vary from $500 \mathrm{~m} \mathrm{a}^{-1}$ in the west, near the Dawson-Lambton Ice Stream, to $1300 \mathrm{~m} \mathrm{a}^{-1}$ in the east, within the Stancomb-Wills Ice Stream.

RÉSUMÉ. Écoulement du Brunt Ice Shelf, Antarctique, à partir de l'imagerie Landsat, 1973-85. Les images satellites de 1973, 1974 et 1985 du Brunt Ice Shelf sont comparées. Il y a suffisamment de repères se déplaçant avec la glace du Shelf pour témoigner des caractéristiques de l'écoulement sur $\sim 10000 \mathrm{~km}^{2}$. Les vitesses varient de $500 \mathrm{~m} \mathrm{an}^{-1}$ à

\section{INTRODUCTION}

Although the flow regime of the Ross Ice Shelf is now fairly well understood, many Antarctic ice shelves remain almost unknown in terms of their velocity fields. The availability of new Landsat images of the Brunt Ice Shelf makes it possible to measure surface velocities by comparing the positions of recognizable features over a period of more than 10 years. Figure 1 shows a composite of two Landsat images recorded in February 1985; a number of features on the ice shelf are clearly visible. Some of these were compared with the same features seen on images recorded in 1973 and 1974; Figure 2 shows the displacements that have occurred across the whole ice shelf over the 11 year interval.

\section{METHOD AND RESULTS}

The two sets of Landsat images used are:

\begin{tabular}{ccccc} 
Path & Row & \multicolumn{2}{c}{ Date } & No. \\
195 & 114 & 22 January 1973 & $1188-09002-7$ \\
190 & 114 & 22 February 1974 & $1579-08270-7$ \\
190 & 115 & 22 February 1974 & $1579-08272-7$ \\
& & & & \\
183 & 113 & 28 February 1985 & $50364-09070-4$ \\
183 & 114 & 28 February 1985 & $50364-09072-4$
\end{tabular}

(Note that band 7 from Landsat 1 is equivalent to band 4 from Landsat 5.)

The 1973 image covers all the coastline and was used with the 1985 images to derive the velocity vectors shown near the coast on the west of Figure 2. Those from 1974 cover the remainder of the area. The 1985 images cover the whole of the area shown.

Details of the ice front, the inland boundary of the ice l'ouest près du courant de Dawson-Lambton Ice Stream, à $1300 \mathrm{~m} \mathrm{an}^{-1}$ à l'est près du courant de Stancomb-Wills Ice Stream.

Zusammenfassung. Das Fliessen des Brunt Ice Shelf. Antarktis, hergeleitet aus Landsat-Bildern, 1974-85. Satellitenbilder des Brunt Ice Shelf von 1973, 1974 und 1985 werden verglichen. Es gibt genügend viele Erscheinungen, die sich mit dem Schelfeis bewegen und Fliessmuster über ein Gebiet von etwa $10000 \mathrm{~km}^{2}$ Grösse erkennen lassen. Für die Geschwindigkeit ergeben sich Werte von $500 \mathrm{~m}$ pro Jahr im Westen nahe dem Dawson-Lambton Ice Stream bis zu $1300 \mathrm{~m}$ pro Jahr im Osten für den Stancomb-Wills Ice Stream. shelf (hinge zone), and other features recognizable on both sets were traced from the images. Location was by the matching of points which are common to both sets of images and were assumed not to have moved in the interval. These are the left bank of the Dawson-Lambton Ice Stream where it meets the coast, the McDonald Ice Rumples (a grounded area), and the long inland boundary of the Brunt Ice Shelf. The other features selected are moving with the ice shelf, their two positions are marked by the two ends of the vector arrows. The numerical values shown in Figure 2 are the mean rates of movement in metres per annum $\left(\mathrm{m} \mathrm{a}^{-1}\right)$ over the 11 year period (12 years for the western coastal vectors). Also shown are the positions of the ice front for 1973 and 1985 . It should be noted that the value of $740 \mathrm{~m} \mathrm{a}^{-1}$ on the western edge was determined by following the movement of an inlet in the ice front, whereas the value $540 \mathrm{~m} \mathrm{a}^{-1}$ was determined from the movement of the ice front itself.

The consistency of the vectors across the ice shelf suggests that the method used is reliable, the accuracy of the results depending on the matching of the two tracings in both position and scale. The tracings were made at the scale of the earlier images $(1: 500000)$, and the possible error in matching varied from less than $1 \mathrm{~mm}\left(50 \mathrm{~m} \mathrm{a}^{-1}\right)$ at the western edge to about $3 \mathrm{~mm}\left(150 \mathrm{~m} \mathrm{a}^{-1}\right)$ in the east away from the inland boundary of the ice shelf. These values, the variations possible in positioning one trace over the other, represent uncertainties in the velocity vectors of from $50 \mathrm{~m} \mathrm{a}^{-1}$ in the west to $150 \mathrm{~m} \mathrm{a}^{-1}$ in the north-east. These uncertainties are not large enough to alter the overall pattern, which is a predominantly north-westerly movement increasing from $800 \mathrm{~m} \mathrm{a}^{-1}$ towards the south-west to $1300 \mathrm{~m} \mathrm{a}^{-1}$ at the Stancomb-Wills Ice Stream (Fig. 2). The ice shelf lying between the grounded area of the McDonald Ice Rumples and the Dawson-Lambton Ice Stream is moving westerly more slowly, at about $500 \mathrm{~m} \mathrm{a}^{-1}$. It can be seen that the velocities shown within the Stancomb-Wills Ice Stream are not significantly higher than those in the adjacent ice shelf. 


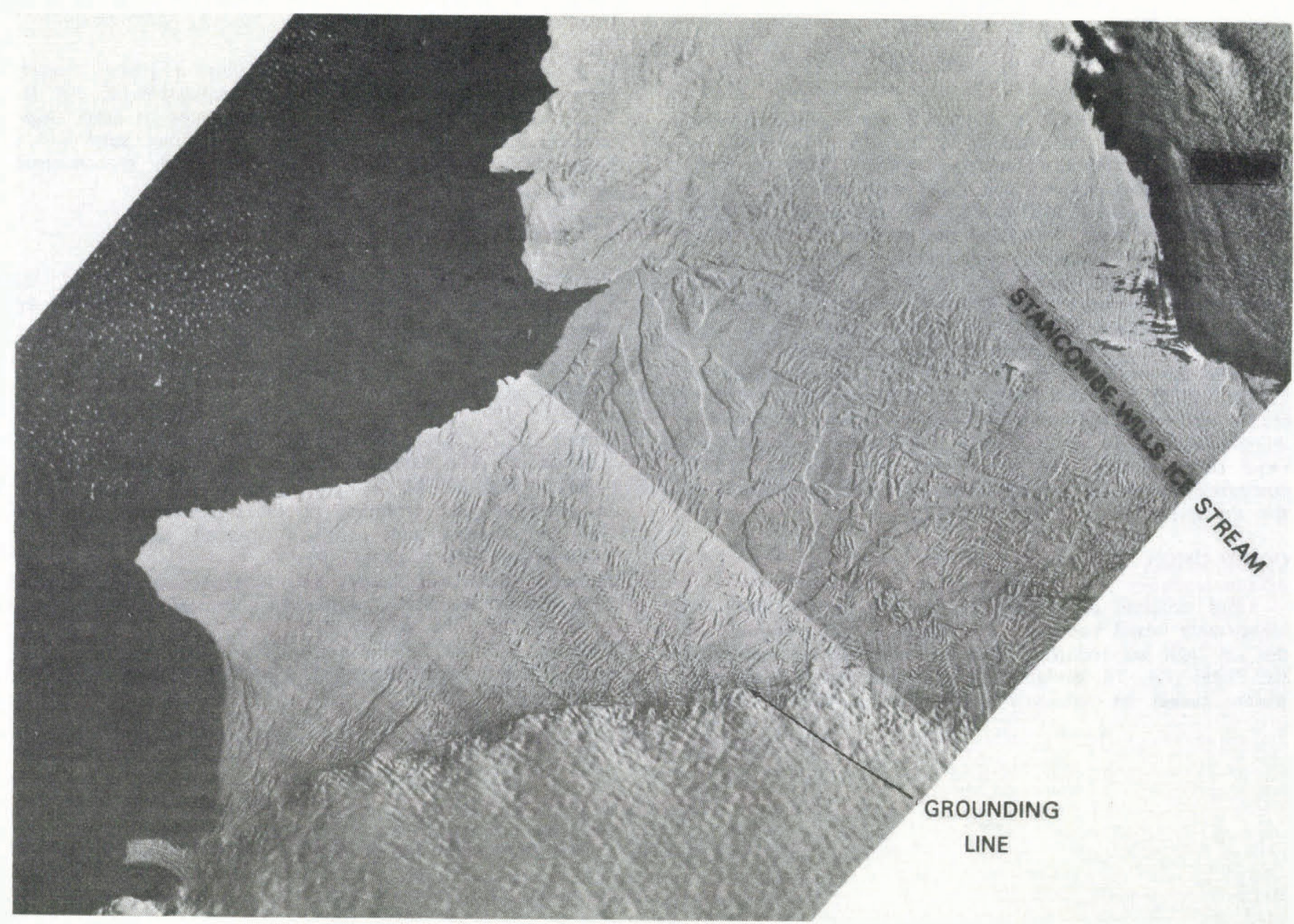

Fig. 1. Composite of 1985 Landsat images of the Brunt Ice Shelf. The latitude and longitude of this area are shown in Figure 2. Note that the dark area in the north-east of the image is not the ice front but shadow from a bank of cloud.

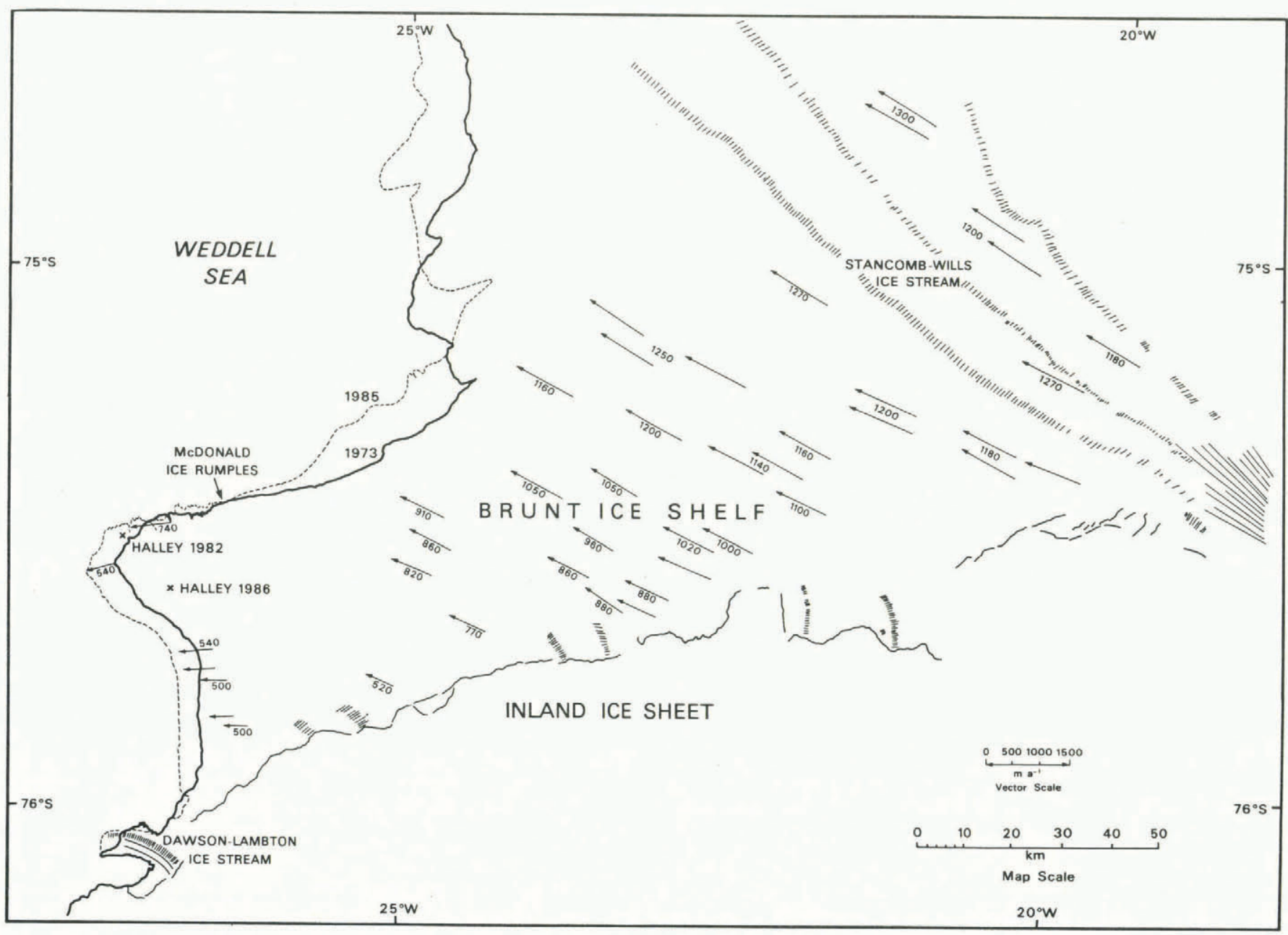

Fig. 2. Diagram of the area shown in Figure 1. The arrows show the movements of individual features from 1974 to 1985 . Values shown are mean rates of movement in metres per annum

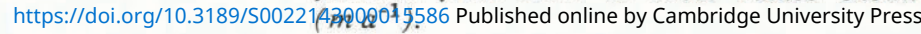




\section{DISCUSSION}

The values shown in Figure 2 are consistent with earlier estimates of the velocity of the Brunt Ice Shelf by Thomas (1973), and Simmons and Rouse (1984). Simmons and Rouse (1984) showed that the British Antarctic Survey station Halley moved at $740 \mathrm{~m} \mathrm{a}^{-1}$ for the period 1972-82; this value was based on fixing the position of the station by astronomical methods, geomagnetic survey, or ships' satellite navigation and radar. Thomas (1973) found velocities in the range $1300-1500 \mathrm{~m} \mathrm{a}^{-1}$ north-east of Halley towards the Stancomb-Wills Ice Stream; these values were based on astronomical methods and ground survey.

The movement of the ice front has been measured by Colvill (1977) and by Lange and Kohnen (1985). Colvill (1977) compared the ice-front position shown on satellite images recorded in 1972-73 with that shown by aerial surveys flown during 1967-68. Lange and Kohnen (1985) compared the ice-front position on two successive cruises of RV Polarstern (1982-83 and 1983-84).

\section{CONCLUSION}

For accurate comparison of Landsat images, both an identifiable inland boundary to, and recognizable features on the ice shelf are required. Both are available for the Brunt Ice Shelf (Fig. 1), giving flow patterns over a wide area which cannot be achieved by comparing satellite images with other observations. The results show a greater consistency than estimates based on the movement of the ice front, whether measured from these images or from ships' observations. They also cover a longer time span and a larger area than would be convenient with ground-based surveying.

\section{ACKNOWLEDGEMENTS}

I should like to thank NASA for the use of the Landsat images, and Dr C. Swithinbank for suggesting the work, and providing help and encouragement.

\section{REFERENCES}

Colvill, A.J. 1977. Movements of Antarctic ice fronts measured from satellite imagery. Polar Record, Vol. 18, No. 115 , p. $390-94$

Lange, M.A., and Kohnen, H. 1985. Ice front fluctuations in the eastern and southern Weddell Sea. Annals of Glaciology, Vol. 6, p. 187-91.

Simmons, D.A., and Rouse, J.R. 1984. Accelerating flow of the Brunt Ice Shelf, Antarctica. Journal of Glaciology, Vol. 30, No. 106, p. 377-80.

Thomas, R.H. 1973. The dynamics of the Brunt Ice Shelf, Coats Land, Antarctica. British Antarctic Survey. Scientific Reports, No. 79. 